\title{
Advancing Strategic Climate Litigation in Brazil
}

\author{
Alessandra Lehmen ${ }^{1}(\mathbb{D}$ \\ ${ }^{1}$ Porto Alegre, Brazil \\ Corresponding author: alehmen@alumni.stanford.edu
}

(Received 19 October 2021; accepted 27 October 2021)

\begin{abstract}
Climate change has become a household term. As the climate crisis grows increasingly pressing, climate litigation has proven instrumental as a driver for change. Brazil is an important jurisdiction for climate matters: It is the sixth largest global greenhouse gas emitter, responsible for 3.2 percent of global emissions, ${ }^{1}$ and home to the largest extension of the Amazon rainforest. Climate litigation has been gaining traction, but it is still far less frequent than environmental litigation at large. Against the backdrop of the state and trends of climate litigation in the country, this article explores theoretical and practical avenues to further expand the strategic deployment of climate cases in Brazil. First, it analyzes how climate claims can be construed with arguments that are impervious to the political question doctrine. Second, it explores possibilities of bringing claims against private entities, challenging more granular obligations arising out of Environmental, Social and Governance (ESG) frameworks. Third, it discusses the role of lawyers in bridging theoretical and practical gaps, namely those between environmental law and climate law, between scientific experts and courts, and between international and domestic climate change regimes.
\end{abstract}

Keywords: Climate law; climate litigation; strategic litigation; Brazil; ESG litigation

\section{A. Introduction}

Climate change litigation has developed significantly in Brazil in the past year. Notable cases in the current wave of litigation in Brazil in which climate change is a central element ${ }^{2}$ include the following: The Climate Fund Case, the first climate claim filed before the Brazilian Supreme Court,

\footnotetext{
Alessandra Lehmen Environmental and climate lawyer admitted in New York and Brazil. Post-doctoral Laureate, Make Our Planet Great Again Program, Presidency of France/CNRS/Aix-Marseille Université. Ph.D., International Law, Federal University of Rio Grande do Sul, Brazil. W50 Leadership Scholar, London School of Economics and Political Science. LL.M., Environmental Law \& Policy, Stanford Law School. MBA, Economics and Corporate Law, Fundacao Getulio Vargas. Vice President, Brazilian Bar Environmental Law Commission, Rio Grande do Sul Chapter. Stanford Woods Institute Rising Environmental Leaders Fellow. Stanford Olaus and Adolph Murie Award for best work in Environmental Law. Lincoln Institute/Harvard Forest Conservation Catalysts Award. Researcher, CNPq-INCT (National Institute for Science and Technology, Brazil). Member, Union of Concerned Scientists Science Network. Member, Centre Nationale de Droit International de l'Environnement (CIDCE). Member, IUCN World Commission on Environmental Law. Board Member, Environmental Council of the City of Porto Alegre, Brazil.

${ }^{1}$ Sistema de Estimativa de Emissões de Gases de Efeito Estufa (SEEG), ANÁlise das emissões brasileiras de Gases DE EFEITO ESTUFA E SUAS IMPLICAÇÕES PARA AS METAS DE CLIMA DO BRASIL 1970-2019 (2020), https://seeg-br.s3.amazonaws. com/Documentos\%20Analiticos/SEEG_8/SEEG8_DOC_ANALITICO_SINTESE_1990-2019.pdf.

${ }^{2}$ For a database of Brazilian climate cases, see JusClima 2030 project, NATIONAL COUnCIL of JustiCE https://jusclima2030. jfrs.jus.br/litigio/.
}

(C) The Author(s) 2022. Published by Cambridge University Press on behalf of the German Law Journal. This is an Open Access article, distributed under the terms of the Creative Commons Attribution licence (https://creativecommons.org/licenses/by/4.0/), which permits unrestricted re-use, distribution, and reproduction in any medium, provided the original work is properly cited. 
challenging the paralysis of the fund's operations and governance; ${ }^{3}$ two cases, filed by political parties, NGOs, and environmental associations, ${ }^{4}$ seeking to enforce the Plan of Action for Prevention and Control of Deforestation in the Amazon (PPCDAm); a case filed by youth challenging the lack of ambition in Brazil's new Nationally Determined Contribution; ${ }^{5}$ a case filed by the association of fossil fuel distributors challenging mandatory acquisition of biofuel certificates (CBio) under the RenovaBio program, which sets annual decarbonization targets for the fossil fuel sector; ${ }^{6}$ a case brought by a group of families against incentives granted to the automotive sector by the State of Sao Paulo, ${ }^{7}$ a case seeking to include evaluation of climate impacts in licensing thermal power plants in the State of Rio Grande do Sul, ${ }^{8}$ and a case brought by the Public Prosecution Service seeking redress of climate damages tied to deforestation in the Amazon. ${ }^{9}$

Brazil experienced a first wave of climate litigation in the first decade of the century, ${ }^{10}$ followed by a somewhat lengthy hiatus, and, from 2020, a renewed interest in bringing climate change to court. An effort to investigate and understand why climate litigation is on the rise in Brazil is needed to not only anticipate litigation trends, but to effectively shape policy. What circumstances drove the renaissance of climate litigation in Brazil?

There are a few that come to mind: The COVID-19 pandemic, and, with it, the realization that climate change increases the risk of future outbreaks; ${ }^{11}$ the ubiquity of the climate emergency debate; ${ }^{12}$ the rise of the ESG agenda; ${ }^{13}$ and the strengthening of an epistemic climate community ${ }^{14}$ in Brazil, comprised of lawyers, judges, scientists, business entities, politicians, prosecutors, academia, NGOs, and subnational governments. The phenomenon is most certainly multifactorial; nevertheless, the most relevant driver for the current wave of climate litigation is the aim, prompted by recent policy and legislative rollbacks, to counter governmental conduct. Indeed, there is a noteworthy common trait among recent higher profile cases: The majority have been filed against governmental entities at federal and state levels.

Climate litigation can be a powerful instrument of climate governance. ${ }^{15}$ Strategic litigation is a method of advocacy, with broad, multifaceted, and often long-term objectives, that develops

\footnotetext{
${ }^{3}$ Action for Non-Compliance with a Fundamental Precept (ADPF) 708 (Braz.); See Alessandra Lehmen \& Caio Borges, Climate Fund Case: Climate Litigation reaches the Brazilian Supreme Court, Oxford Hum. RTs. Hub (Jul. 24, 2020), https://ohrh.law.ox.ac.uk/climate-fund-case-climate-litigation-reaches-the-brazilian-supreme-court/.

${ }^{4}$ Action for Non-Compliance with a Fundamental Precept (ADPF) 760; Public Civil Action No. 504895139.2020.4.04.7000/PR (Braz.).

${ }^{5}$ Popular Action No. 5008035-37.2021.4.03.6100/SP (Braz.).

${ }^{6}$ Writ of Mandamus MS 27093/DF (Braz.).

${ }^{7}$ Motion to Compel Discovery 1047315-47.2020.8.26.0053/SP (Braz.).

${ }^{8}$ Public Civil Action No. 5030786-95.2021.4.04.7100/RS (Braz.).

${ }^{9}$ Public Civil Action No. 1005885-78.2021.4.01.3200/AM (Braz.).

${ }^{10}$ See, e.g., Public Prosecutor's Office v. United Airlines, Public Civil Action No. 000292010.2014.4.03.9999 (seeking carbon offsets related to airline operations in the Sao Paulo international airport); Public Prosecutor's Office v. Oliveira, No. 2008/ 0215494-3 (regarding greenhouse gas emissions from sugar cane burning as a harvesting and processing method); Public Prosecutor's Office v. H Carlos Schneider S/A Comércio e Indústria, Special Appeal 650.728 - SC (regarding environ mental and climate harms resulting from draining and clearing a mangrove forest).

${ }^{11}$ Preventing the Next Pandemic: Zoonotic Diseases and How to Break the Chain of Transmission, U.N. ENVIRONMENT Programme and International Livestock Research Institute (Jul. 6, 2020), https://www.unep.org/resources/report/ preventing-future-zoonotic-disease-outbreaks-protecting-environment-animals-and.

${ }^{12}$ See generally Alessandra Lehmen, Populism, Environmental Law, and the Post-Pandemic Order, 17 BRAZILIAN J. INT'L L. 84-99, n. 2 (2020).

${ }^{13}$ See Georg Kell, The Remarkable Rise Of ESG, ForBEs (Jul. 11, 2018), https://www.forbes.com/sites/georgkell/2018/07/11/ the-remarkable-rise-of-esg/?sh=5280e06a1695.

${ }^{14}$ See generally Peter M. Haas, Introduction: Epistemic Communities and International Policy Coordination, 46 INT'L ORG. 1-35 (1992).

${ }^{15}$ See generally Samvel Varvastian, Climate Change Litigation, Liability and Global Climate Governance-Can Judicial Policy-Making Become a Game-Changer?, Berlin Conference on Global Environmental Change: Transformative Global Climate Governance "après Paris" (2016), https://refubium.fu-berlin.de/handle/fub188/18585; Ana Maria Nusdeo,
} 
before courts or other international or domestic venues and mechanisms of redress. ${ }^{16}$ Success in strategic climate litigation is, therefore, polysemic: Sometimes the mere filing of a climate lawsuit is in itself a driver for change. As the current global wave of climate litigation shows no sign of receding, ${ }^{17}$ and, more importantly, progressively achieves positive and tangible outcomes for plaintiffs, relevant actors more often than not take the risk of litigation into account, which is another way in which climate litigation shapes action. With this in mind, this article seeks to analyze legal strategies to advance climate litigation in Brazil, organizing them around three main themes. First, we analyze if, and how, climate claims can avert the political question doctrine, comparing climate cases from other jurisdictions that dealt with the matter. Second, we explore the possibility of reframing climate litigation as ESG litigation. Third, we discuss the role of lawyers in bridging conceptual and empirical gaps and contributing to the development of climate law, namely those between environmental law and climate law, between scientific experts and courts, and between international and domestic climate change regimes. While Brazil is the focus of this article, many of the lessons arising out of the analysis of climate litigation in the country are potentially transferrable to other jurisdictions.

\section{B. Climate Constitutionalism and the Political Question Doctrine}

Particularly after the Climate Fund Case reached the Supreme Court, the debate on climate constitutionalism has been gaining traction in Brazil. This section analyzes potential roadblocks to climate litigation that may stem from the Brazilian constitutional system-namely, the separation of powers defense-proceeds to compare climate cases from other jurisdictions that dealt with the issue, and considers whether, and under which conditions, Brazilian cases can sidestep these hurdles.

There has been some debate on the recognition of a new constitutional right to a stable and healthy climate in Brazil. ${ }^{18}$ Although clear enunciation of such a right is useful and welcome, particularly as a shield against policy rollbacks, it is not sufficient, nor is it necessary, for effective adjudication of climate matters. This is because the right to a balanced and stable climate is a logical and inexorable corollary of the fundamental right to an ecologically balanced environment, provided for in Article 225 of the Brazilian Constitution of 1988. Government actions and omissions to the detriment of the effectiveness of the constitutional protection of the environment, and, consequently, the right to a balanced climate, constitute, therefore, a constitutional matter necessarily linked to the sphere of action of the Judiciary.

The Brazilian constitutional and infra-constitutional legal system needs to be shielded from regression, and it also needs to advance in order to address the pressing question of concrete implementation of the country's climate commitments. Regulation on the more granular aspects of climate policy, that is, how they translate in terms of rights and obligations for all relevant state and non-state stakeholders, would be of invaluable importance for the implementation of climate rights. At the level of principles and fundamental rights, however, the Brazilian legal system already provides, in its current state, a robust framework for adjudication of climate claims.

\footnotetext{
Litigância e governança climática. Possíveis impactos e implicações, in LitigÂNCIA ClimátiCA - Novas FRONTEIRAS PARA O Direito Ambiental no Brasil, 139-54 (Kamila Cunha, Amália F. Botter \& Joana Setzer eds., 2019).

${ }^{16}$ See Michael Ramsden \& Kris Gledhill, Defining Strategic Litigation, 407 CIV. JusT. Q. 4 (2019).

${ }^{17}$ For an updated overview of the state of climate litigation worldwide, see the Global Climate Litigation Report: 2020 Status Review (GCLR), U.N. ENVIRONMENT Programme, (2020), https://wedocs.unep.org/bitstream/handle/20.500.11822/34818/ GCLR.pdf?sequence $=1$ \&isAllowed $=y$.

${ }^{18}$ See generally Ingo Wolfgang Sarlet, Direito fundamental a um clima estável e a PEC 233/2019 (2020), https://www.conjur. com.br/2020-dez-14/direto-fundamental-clima-estavel-pec-2332019; Gabriel Wedy, Maiara Camine, Eliana Rhoden \& Tatiana Arnhold, Direito fundamental ao clima estável e a audiência do fundo ambiental (2020), https://www.conjur.com. br/2020-out-10/ambiente-juridico-direito-fundamental-clima-estavel-audiencia-fundo-clima. A bill for constitutional amendment, aiming at including the right to a stable climate in Article 225, was proposed by a group of congresspeople in 2021.
} 
From the standpoint of strategic litigation, perhaps the biggest question regarding climate constitutionalism is not whether a right to a stable climate exists-something few would dare to deny, particularly in light of the climate crisis-but whether climate claims can overcome the Judicialization of Politics ${ }^{19}$ hurdle. The separation of powers defense, roughly equivalent in Brazil to the political question doctrine in the United States, ${ }^{20}$ posits that the Judiciary cannot substitute the legislative and the executive in legislating and in determining public policy. ${ }^{21}$

Although climate claims can, and should, target lacking or poorly enforced climate policies, they cannot determine the contents of said policies. It is fundamental, therefore, to reflect on how to advance climate rights without resorting to judicial consequentialism and the controversies that surround it. ${ }^{22}$ It is also vital to ponder how to construe a right to a stable climate with arguments that are impervious to the separation of powers defense and, as a consequence, more likely to be conducive to successful litigation. In this context, the issue of whether, and within what limits, courts can decide on rights and obligations related to climate change is of the essence. In order to do so, it is useful to compare approaches from other jurisdictions, and to analyze how they could translate to the novel context of Brazilian climate litigation.

The history of the development of the modern state is intertwined with the evolution of the control of power, ${ }^{23}$ and the question of the division and limitation of state power remains vital to contemporary constitutionalism. Today, most democratic states are organized under a model of separation of powers, in which primary state functions are assigned to independent and specialized branches and a checks and balances mechanism is in place, designed to prevent disproportionate concentration of powers in any of these branches, and, ultimately, to avert risks to democracy and fundamental rights.

The defense based on separation of powers is characterized in the United States by a specific emanation, the political question doctrine, established in 1962 in Baker v. Carr. ${ }^{24}$ Although scantily used since then - to the point that the U.S. Supreme Court has not applied it to the highly political Bush v. Gore ${ }^{25}$ - the doctrine was revived as a defense in climate cases. This contextualization is important, as the generalization of the defense of separation of powers in climate litigation is problematic. The Baker Test consists of six points upon which acceptance of the separation of powers defense is conditioned. The test was applied to tort-based cases and focused on the first three prongs: The express constitutional attribution of the issue to another political entity, the absence of judicial standards for the resolution of the matter, or the impossibility of deciding the case without invading the realm of public policy formulation. ${ }^{26}$

\footnotetext{
${ }^{19}$ See Ran Hirschl, The Judicialization of Politics, in The Oxford Handbook OF Political ScIEnCE (Robert E. Goodin ed., 2011).

${ }^{20}$ See generally Matheus Barra de Souza, A Political Question Doctrine no direito brasileiro (Feb. 13, 2020) (Bachelor of Law Course Completion Paper, University of Brasília); Flávia Danielle Santiago Lima \& José Mário Wanderley Gomes Neto, $A$ Brazilian Self-Restraint? A Taxonomy of Legal Arguments (and Political Strategies?) Which Explain the Behavior of the Supreme Court in Relations with the Major Branches of Power, 5 RevisTA DE INVESTIGAÇÕES CONSTITUCIONAIS 221-47 (2018).

${ }^{21}$ See Manoel Gonçalves Ferreira Filho, A separação dos poderes: a doutrina e sua concretização constitucional, 16 Cadernos Jurídicos da Escola Paulista da Magistratura, 67-81 (2015).

${ }^{22}$ See generally Klaus Mathis, Consequentialism in Law, in EFFICIENCY, Sustainability, AND JUSTICE TO FUTURE Generations, 3-29 (Klaus Mathis ed., 2012); Rômulo Guilherme Leitão \& José Patriarca Brandão Souza, Questões políticas e Supremo Tribunal Federal: da autolimitação ao moralismo, in REviSTA DA FACULDADE DE DIREITO DA UFRGS 189-204 (2018); Robert Guay, A Refutation of Consequentialism, in 36 METAPHILOSOPHY 348-62 (2005).

${ }^{23}$ See C. Perry Patterson, The Evolution of Constitutionalism, 32 MinN. L. REv. 427 (1948).

${ }^{24}$ Baker v. Carr, 369 U.S. 186 (1962).

${ }^{25}$ Bush v. Gore, 531 U.S. 98 (2000).

${ }^{26}$ Comparative Law_Climate Change-Hague Court of Appeal Requires Dutch Government to Meet Greenhouse Gas Emissions Reductions by 2020-Hof's-Gravenhage 9 oktober 2018, AB 2018, 417 m.nt. GA van der Veen, Ch.W. Backes (Staat der Nederlanden/Stichting Urgenda), 132 HARV. L. REV. 2090 (2019), https://harvardlawreview.org/wp-content/ uploads/2019/05/2090-2097_Online.pdf.
} 
Beyond the United States, more recent cases demonstrate that the test does not have the power to prevent judicial review of climate disputes. Particularly noteworthy is the celebrated Urgenda $v$. Netherlands, ${ }^{27}$ which refuted the separation of powers argument in a paradigmatic manner. In Urgenda, the Dutch government argued that a court order requiring the state to limit its greenhouse gas emissions would violate the separation of powers doctrine, as a decision that democratically elected leaders should take would be improperly placed in the hands of the Judiciary. The court disagreed, concluding that Dutch law requires the Judiciary to review the actions of other powers whenever the rights of citizens are at stake, even if the resolution of the case has political consequences. The court asserted that the Urgenda requests essentially concern the protection of rights, and are, therefore, justiciable.

Urgenda thus illustrates why cases based on climate rights surpass the three formulations of the Baker Test: The first, because the matter is not exclusively in the interest of another power, and the required measure leaves the political powers sufficient leeway for the formulation of policies; the second, because determining whether an action by the federal government violates constitutional rights is standard practice of the Judiciary; the third, because deciding the case does not require the Judiciary to politically determine the "best" level of emissions or how to achieve it, leaving a significant margin of discretion to the Executive.

Circling back to United States jurisprudence, the dissenting vote cast by Judge Josephine Staton in the emblematic Juliana $v$. United States ${ }^{28}$ teaches an important lesson regarding the limits and proper application of the doctrine of separation of powers, which can be summarized as follows: The political question doctrine is not incompatible with the judicial review doctrine, and the judiciary should not be prevented from acting, for excessive attachment to the first doctrine, when other powers "walk the Nation over a cliff." Judicial review is, essentially, the fundamental idea that the actions of the Executive and Legislative branches are subject to review, and possible invalidation, by the Judiciary. In this particular sense, the U.S. and Brazilian legal systems are similar. ${ }^{29}$

In the same vein, there is a tendency of increased judicialization of constitutional issues in Brazil. There is, however, no intrinsic incompatibility between judicialization and separation of powers. Supreme Court Justice Luís Roberto Barroso clarifies that "conservation and promotion of fundamental rights, even against the will of political majorities, is a condition for the functioning of democratic constitutionalism. Therefore, intervention of the Judiciary, in such cases, remedying a legislative omission or invalidating an unconstitutional law, is in favor and not against democracy." 30 The Judiciary is not exclusively responsible for interpreting the Constitution-all three powers do so, within the limits of their attributions-but it is inherent to the Brazilian institutional arrangement that the final word in this regard is given by courts. ${ }^{31}$

There are, however, limits to adjudication that are imposed by separation of powers, in that courts cannot mandate the creation of particular policies. In that sense, a lot hinges on how the

\footnotetext{
${ }^{27}$ Hof s-Gravenhage 9 oktober 2018, AB 2018, 417 m.nt. GA van der Veen, Ch.W. Backes (Staat der Nederlanden/Stichting Urgenda) (Neth.), http://blogs2.law.columbia.edu/climate-change-litigation/wp-content/uploads/sites/16/non-us-casedocuments/2020/20200113_2015-HAZA-C0900456689_judgment.pdf.

${ }^{28}$ Juliana v. United States, 947 F.3d 1159 (9th Cir. 2020):

Our tripartite system of government is often and aptly described as one of 'checks and balances.' The doctrine of standing preserves balance among the branches by keeping separate questions of general governance and those of specific legal entitlement. But the doctrine of judicial review compels federal courts to fashion and effectuate relief to right legal wrongs, even when - as frequently happens - it requires that we instruct the other branches as to the constitutional limitations on their power.

${ }^{29}$ Brazil's 1988 constitutional design combines, however, two models of judicial review, diffuse or concrete, and concentrated or abstract, both exercised by the Judiciary. See Victor de Queiroz Barbosa \& Ernani Carvalho, The Supreme Federal Court as Queen of Chess: Partisan Fragmentation and Judicial Empowerment, in 28 Revista De Sociologia E PolítiCa 73 (2020).

${ }^{30}$ See Luís Roberto Barroso, Judicialização, ativismo judicial e legitimidade democrática, in 5 SUFFRAGIUM - REVISTA DO Tribunal Regional Eleitoral do Ceará 11-22 (2009).

${ }^{31}$ See generally Keith S. Rosenn, Separation of Powers in Brazil, 47 DUQ. L. REV. 839 (2009).
} 
claim is framed. The first climate case to reach the Supreme Court-the Climate Fund Case, filed in 2020 — ${ }^{32}$ illustrates this point. The Climate Fund is an accounting fund created by Law nr. 12.114/09, which is an instrument of the National Policy on Climate Change (Law nr. 12.187/ 09). ${ }^{33}$ The Climate Fund Case seeks to compel the Executive to guarantee the regular functioning of the fund by reconvening its committee and releasing budgets that had already been allocated.

The Climate Fund Case, therefore, seeks judicial relief specifically regarding concrete non-compliance with public policies that were set forth by regular legislative process. The claim is limited to compelling the Executive to comply with the norms that govern operation of the Climate Fund. In this regard, the decision in Friends of the Irish Environment (FIE) v. Ireland ${ }^{34}$ is particularly enlightening, as the Irish court has recognized that the climate policy in question has been recognized in law, and that the Judiciary has the primary function of ensuring its application. The court did not address general human rights arguments applied to the environment and climate, but found the breach of the law objectively verifiable, and ordered the Irish government to take steps to comply. The same occurs with respect to the set of norms that govern the Climate Fund: Once their non-compliance with the law is verified, the Supreme Court has powers to determine that they are observed, especially in view of the climate commitments adopted by Brazil at the international and domestic levels.

Although the Climate Fund Case lends itself to a wider discussion of climate law in Brazil, and it is still in somewhat early procedural stages, its object corresponds rather strictly to policy that has already been passed into law, and, specifically, to concrete aspects of said law. As such, it does not interfere with the policymaking powers of the executive or the legislative, and has good prospects of sidestepping the separation of powers roadblock.

The main takeaway is that going beyond loftier fundamental rights arguments and crafting claims that also offer more granular arguments, both factual and legal, is highly desirable from a litigation strategy standpoint. The next section discusses possible avenues for this to take place.

\section{Beyond Government: Framing Climate Litigation as ESG Litigation}

A distinctive feature of climate litigation in the Global South is a prevalence of rights-based claims, ${ }^{35}$ and this holds generally true with regard to the recent wave of litigation in Brazil.

Achieving the goals of the international regime of climate change, however, is unattainable without involvement of the private sector. It is vital, therefore, to develop climate litigation strategies focusing on non-state actors.

Although it is not a new concept, ${ }^{36}$ ESG-Environmental, Social, and Governance-became something of a buzzword in the 2020 post-pandemic scenario. I anticipate that, moving forward, ESG litigation will be on the rise. Climate change is an important part of ESG, and ESG is becoming increasingly regulated. The relevance of this shift from voluntary to mandatory obligations has implications for climate litigation that cannot be understated.

Indeed, in the wake of the increased centrality of ESG, several developments have the potential of triggering litigation, opening the door for judicial and extrajudicial cases, transnational and domestic, initiated by a myriad of stakeholders, such as shareholders, investors, NGOs, the

\footnotetext{
${ }^{32}$ Action for Non-Compliance with a Fundamental Precept (ADPF) 708 (Braz.).

${ }^{33}$ Law nr. 12.187/09.

${ }^{34}$ Friends of the Irish Environment v. Ireland, [2020] JR 793 JR (SC) (Ir.) ("It may have been the policy of a particular government to introduce the legislation in question but once that legislation is passed it then become law and not policy.").

${ }^{35}$ See Jaqueline Peel \& Jolene Lin, Transnational Climate Litigation: The Contribution of the Global South, 113 AJIL UNBOUND 679 (2019).

${ }^{36}$ See generally, Who Cares Wins - Connecting Financial Markets to a Changing World, The Global COMPACT (2004), https://d306pr3pise04h.cloudfront.net/docs/issues_doc\%2FFinancial_markets\%2Fwho_cares_who_wins.pdf; A legal framework for the integration of environmental, social and governance issues into institutional investment, U.N. ENVIRONMENT Programme Finance Initiative (2005), https://www.unepfi.org/fileadmin/documents/freshfields_legal_resp_20051123.pdf.
} 
Public Prosecution Service, the public, and, in the particular case of Brazil, other actors that have standing, such as political parties, associations, and the Bar.

While it is true that ESG still involves a good deal of self-regulation, there is a clear tendency towards heightened regulatory scrutiny. As with financial disclosures, the world is moving towards harmonization and comparability of non-financial disclosures-International Financial Reporting Standards (IFRS) ${ }^{37}$ and International Organization of Securities Commissions (IOSCO) ${ }^{38}$ initiatives, for example - and, at the same time, towards increasingly mandatory standards. Robust examples of this movement are adoption of disclosures based on the Task Force on ClimateRelated Disclosures (TCFD) - in the $\mathrm{UK}^{39}$ and in Brazil, ${ }^{40}$ for example, and, in the U.S., recent Federal Reserve ${ }^{41}$ and Securities and Exchange Commission (SEC) ${ }^{42}$ initiatives to take ESG and climate-related risks expressly into account.

ESG and climate responsibility of financial institutions are likely to become a focus of litigation. Indeed, there is increasing awareness that, without restricting the flow of cash to high-emitting activities, there is little chance of meeting the goals of the Paris Agreement. ${ }^{43}$ Only a minority of financial firms are taking action, however: A quarter measure their financed emissions, and almost half conduct no climate-related analysis on their portfolios. ${ }^{44}$

These developments are not limited to private financial institutions. Development financial institutions, particularly in emerging economies, play an important role and have been facing heightened scrutiny over the climate impacts of their activities. ${ }^{45}$ At a summit held in November 2020, the world's public development banks pledged to align their financial firepower with the Paris Agreement, but avoided a firm commitment to phase out fossil fuel financing. ${ }^{46}$ As a source of funding for many large infrastructure projects, including in the energy sector, public development institutions are key to efforts to steer finance away from fossil fuels and into low-carbon projects. Together, such institutions invest around $\$ 2.3$ trillion each year-equivalent to ten percent of all global investments from public and private sources. ${ }^{47}$ The World Bank's new

\footnotetext{
${ }^{37}$ Consultation Paper on Sustainability Reporting, IFRS FOUNDATION (2020), https://cdn.ifrs.org/-/media/project/ sustainability-reporting/consultation-paper-on-sustainability-reporting.pdf?la=en.

${ }^{38}$ Climate change and finance: What's next for global regulators? Climate Risk and Green Finance Regulatory Forum 2021, InTERnATIONAL ORGANIZATION OF SECURITIES COMMissions (2021), https://www.sfc.hk/-/media/EN/files/ER/PDF/CEO_ Speech_Climate-Risk-and-Green-Finance-Regulatory-Forum-2021.pdf.

${ }^{39}$ Interim Report and Roadmap, UK JOINT REgULATOR AND GOVERNMENT TCFD TASKFORCE (2020), https://www.gov.uk/ government/publications/uk-joint-regulator-and-government-tcfd-taskforce-interim-report-and-roadmap.

${ }^{40}$ Joint Statement by the Economy Minister of Brazil and the Chancellor of the Exchequer of the UK at the Fourth UKBrazil Economic and Financial Dialogue (Dec. 10, 2020), https://www.gov.br/economia/pt-br/assuntos/noticias/2020/ dezembro-1/arquivos/clean-8th-draft-efd-joint-statement.pdf.

${ }^{41}$ Celso Brunetti, Benjamin Dennis, Dylan Gates, Diana Hancock, David Ignell, Elizabeth K. Kiser, Gurubala Kotta, Anna Kovner, Richard J. Rosen \& Nicholas K. Tabor, FEDS Notes: Climate Change and Financial Stability, FEDERAL RESERVE SYSTEM (Mar. 19, 2021), https://www.federalreserve.gov/econres/notes/feds-notes/climate-change-and-financial-stability20210319.htm.

${ }^{42}$ SEC Response to Climate and ESG Risks, SECURITIES EXCHANGe COMMISsION (May 28, 2021), https://www.sec.gov/secresponse-climate-and-esg-risks-and-opportunities.

${ }^{43}$ Saijel Kishan, Fighting Climate Change by Shutting Down the Money Pipeline, Bloomberg (Feb. 4, 2021), https://www. bloomberg.com/news/articles/2021-02-04/climate-change-environmentalists-target-banks-to-cut-off-fossil-fuel-funding.

${ }^{44}$ See Joseph Power, Jordan McDonald, So Lefebvre \& Tom Coleman, The Time to Green Finance - CDP Financial Service Disclosure Report 2020 (2020), https://6fefcbb86e61af1b2fc4-c70d8ead6ced550b4d987d7c03fcdd1d.ssl.cf3.rackcdn.com/cms/ reports/documents/000/005/741/original/CDP-Financial-Services-Disclosure-Report-2020.pdf?1619537981.

${ }^{45}$ See Alice Pauthier, By COP26 Development Banks Must Go Beyond Climate Finance to Align with Paris, INSTITUTE FOR Climate Economics (Jun. 17, 2021), https://www.i4ce.org/by-cop26-development-banks-mut-go-beyond-climate-financeto-align-with-paris/.

${ }^{46} 450$ Public Development Banks Pledge to Align with Paris Agreement, IISD (Nov. 16, 2020), https://sdg.iisd.org/news/450public-development-banks-pledge-to-align-with-paris-agreement/.

${ }^{47}$ Kate Abnett, Simon Jessop \& Matthew Green, Development Banks Make Landmark Climate Pledge, but no Fossil Fuel Phase Out, REUTERS (Nov. 11, 2020), https://www.reuters.com/article/uk-climate-change-finance-development/developmentbanks-make-landmark-climate-pledge-but-no-fossil-fuel-phase-out-idUKKBN27R30F.
} 
climate action plan, for instance, pledged to align 100 percent of new operations with Paris Agreement goals. ${ }^{48}$ Also notably, the US Treasury, the largest shareholder in major development banks, including the World Bank Group and the African Development Bank, issued new energy financing guidance stating that the United States will oppose their involvement in fossil fuel projects. ${ }^{49}$

In Brazil, too, climate has been increasingly regulated within the framework of ESG rules. Several recent developments regarding ESG regulation are noteworthy. Reform of the securities exchange commission (CVM) Instruction $480^{50}$ is expected to order public companies to periodically disclose non-financial ESG information-a welcome initiative, although the level of detail of the disclosures is yet to be defined.

Oversight of financing of high-impact projects is also on the rise: The Brazilian Central Bank has recently launched three public consultations on the sustainability criteria applicable to rural credit, on regulation of risk management and social, environmental and climate responsibility, and on the annual disclosure, by financial institutions, of a standardized Social, Environmental and Climate Risks and Opportunities Report (the GRSAC Report), ${ }^{51}$ respectively. The GRSAC proposal is inspired by the recommendations of the Task Force on Climate-related Financial Disclosures (TCFD), but its expanded scope also encompasses ESG aspects at large. Its first phase covers qualitative aspects, and its second phase, scheduled for 2022, will establish mandatory disclosures of quantitative information-goals and metrics. Conversely, however, the Lower House has passed a bill exempting financial institutions of environmental liability regarding the activities they finance-a provision that, as of this writing, may still be reversed by the Senate, ${ }^{52}$ and is at odds with the mounting perception that shutting down the money pipeline is key to reducing activities that are ESG-noncompliant. Furthermore, given the prominent role of development banks in the climate crisis, it would be expected of Brazil's National Development Bank (BNDES) that it would follow the lead of its foreign counterparts, moving beyond one-off sustainable credit initiatives and creating mechanisms to effectively integrate climate into its investment and financing decisions and policies.

With regard to public companies, shareholder activism is likely to demand transparent disclosures, stress testing for climate resilience, low-carbon transitioning, and responsible divestment. As a corollary of this trend, we may witness a new wave of cases premised on fiduciary duty theories. Also, beyond traditional consumer misinformation claims, stakeholder capitalism shall spotlight matters of climate justice, such as climate racism and climate impacts on social and gender inequality, that may become increasingly prominent arguments in climate cases, such as those related to exacerbation of health issues by climate factors and their disproportionate impact on vulnerable communities.

Deforestation of the Amazon is largely driven by the production of agricultural and livestock commodities, mainly cattle and soybeans. Climate change in Brazil is, in turn, extensively linked to land use and deforestation. ${ }^{53}$ The recent centrality of ESG has the potential to put additional

\footnotetext{
${ }^{48}$ World Bank Group Climate Change Action Plan 2021-2025: Supporting Green, Resilient, and Inclusive Development, WORLD BANK (Jun. 22, 2021), https://openknowledge.worldbank.org/handle/10986/35799.

${ }^{49}$ Guidance on Fossil Fuel Energy at the Multilateral Development Banks, U.S. TrEASURY (2021), https://home.treasury.gov/ system/files/136/Fossil-Fuel-Energy-Guidance-for-the-Multilateral-Development-Banks.pdf.

${ }^{50}$ Comissão de Valores Mobiliários (CVM), Public Hearing SDM 09/20, (Mar. 8, 2021), http://conteudo.cvm.gov.br/ audiencias_publicas/ap_sdm/2020/sdm0920.html.

${ }^{51}$ Public Consultations - Sustainability, CENTRAL BANK OF BRAZIL, https://www.bcb.gov.br/en/financialstability/ sustainability_public_consultation.

${ }^{52}$ Jake Spring, Brazil's Lower House Passes Bill to Ease Environmental Permits, ReuTers (May 13, 2021), https://www. reuters.com/business/environment/brazils-lower-house-passes-bill-ease-environmental-permits-2021-05-13/.

${ }^{53}$ See Carlos A. Nobre, Gilvan Sampaio, Laura S. Borma, Juan Carlos Castilla-Rubio, José S. Silva \& Manoel Cardoso, LandUse and Climate Change Risks in the Amazon and the Need of a Novel Sustainable Development Paradigm, 113 Proc. NAT'L ACAD. SCIS. 39 (2016).
} 
spotlight on the Amazon. Much of the commodities produced in the Amazon are exported, and tighter rules to halt imported deforestation and outsourced emissions resulting from the consumption in relevant external markets, carbon pricing initiatives, and trade barriers such as the EU Carbon Border Adjustment Mechanism (CBAM) are sure to affect Brazil's economy.

Strategies for ESG disputes should also consider avenues that unfold outside the courtroom, for example before the Organization for Economic Co-operation and Development (OECD), the World Trade Organization (WTO), ${ }^{54}$ and securities or advertisement regulators. The same holds true with regard to transnational ESG litigation. Examples include claims challenging pollution and emissions outsourcing, that is, targeting entities that are relatively cleaner in their countries of origin, but are major polluters in other jurisdictions - for example, the Total, EDF and Casino cases, based on the French Duty of Vigilance Act of 2017, ${ }^{55}$ challenging activities in Uganda, Mexico, and Brazil and Colombia, respectively - supply chain disputes spanning multiple jurisdictions, or disputes under trade agreements, which increasingly involve sensitive and potentially contentious environmental and climate issues.

Finally, it is important to bear in mind that climate litigation can be initiated to challenge climate obligations, not only to uphold them. Reputational risks aside, companies shall increasingly take the offensive and initiate litigation challenging ESG and climate obligations. Investor-state dispute settlement (ISDS), for instance, is a system through which investors can sue countries for discriminatory practices, and has been criticized, particularly the procedures related to the Energy Charter Treaty, ${ }^{56}$ as capable of hindering ambitious climate action. For instance, energy companies filed cases against sovereign governments seeking compensation for stranded assets that will result from coal phase-out policies. ${ }^{57}$ The Court of Justice of the European Union, however, held ongoing ISDS proceedings within the EU are illegal. ${ }^{58}$

These are major developments that need to be adequately taken into account when devising future strategies for climate litigation. As we envision it, this process encompasses two complementary avenues that can be explored by litigators. On the one hand, ESG reporting processes have been progressively incorporating human rights obligations, particularly with regard to its "S" portion. ${ }^{59}$ On the other hand, climate change is ubiquitous and transversal to all three letters of the acronym. As ESG obligations progressively become mandatory and more stringent across jurisdictions - a trend that seems inexorable—climate litigators shall be able to deploy arguments challenging concrete, objective ESG obligations_-such as those based on fiduciary duty, direct and indirect supply chain liability, disclosure obligations, and corporate greenwashing - that both reinforce and confer much-needed granularity to catch-all human rights concepts.

In sum, ESG-based litigation can be deployed strategically to accelerate these most-needed shifts where there is refusal or reluctance to implement them. Perhaps more importantly, litigation may help consolidate the concept of double materiality, by seeking that the private sector observes criteria regarding, on the one hand, sustainability factors affecting the business-financial

\footnotetext{
${ }^{54}$ See J. Ryu \& R.W. Stone, Plaintiffs by Proxy: A Firm-Level Approach to WTO Dispute Resolution. 13 REV. INT'L ORG. 273308 (2018).

${ }^{55}$ See Elsa Savourey \& Stéphane Brabant, The French Law on the Duty of Vigilance: Theoretical and Practical Challenges Since its Adoption, in 6 Bus. \& HuM. RTs. J. 141-52 (2021).

${ }^{56}$ See Kyla Tienhaara \& Christian Downie, Risky Business? The Energy Charter Treaty, Renewable Energy, and Investor-State Disputes, 24 Glob. Governance: Rev. Multilateralism \& InT'L Org. 451-71 (2018).

${ }^{57}$ See Kyla Tienhaara, Regulatory Chill in a Warming World: The Threat to Climate Policy Posed by Investor-State Dispute Settlement, 7 TRANSNAT'L ENV'T L. 229-50 (2018)

${ }^{58}$ ECJ, Case C-741/19, Republic of Moldova v. Komstroy LLC, ECLI:EU:C:2021:164 (Mar. 3, 2021), https://curia.europa.eu/ juris/document/document.jsf;jsessionid=EBC2538F95DAD67DD3FB8BC66A608290?text=\&docid=245528\&pageIndex= $0 \&$ doclang $=$ PL\&mode $=$ lst $\&$ dir $=\&$ occ $=$ first $\&$ part $=1 \&$ cid $=4672299$

${ }^{59}$ See John G. Ruggie \& Emily K. Middleton, Money, Millennials and Human Rights: Sustaining 'Sustainable Investing,' 10 GLOB. POL'y 144-50 (2019).
} 
materiality - and, on the other hand, how the activities carried out by the business affect the environment, climate change, and society at large - outward materiality.

Beyond procedure, ESG litigation will require in-depth knowledge of sophisticated scientific, economic, and legal material concepts, as well as a great deal of transversal and strategic thinking. The substantial body of knowledge amassed in cutting-edge climate litigation in recent years will be instrumental to deal with the upcoming wave of ESG litigation. Rights-based approaches can provide a robust framework in which to argue such cases, while ESG-based litigation can unfold in terms of challenging non-compliance with specific obligations, helping overcome procedural hurdles typically found in climate cases, such as those related to attribution, standing, and justiciability.

\section{Bridging Gaps and Paving the Way for Climate Law: The Role of Lawyers}

It is of the utmost importance, for the advancement of climate law in general and of climate litigation in particular, to equip relevant actors and stakeholders with the specific knowledge to navigate climate matters.

There are three main gaps that we identify as crucial for the development of climate law: First, the gap between environmental law and climate law; second, the gap between scientific experts and courts; and third, the gap between international and domestic climate regimes. Lawyers, and legal professionals in general, play an important role in assessing and devising solutions for these issues, thus contributing to the development and the affirmation of climate law as an independent domain. ${ }^{60}$

As for the first gap, 57,449 environmental cases have been filed in Brazil in 2020 alone. ${ }^{61}$ By contrast, despite the growth observed in the past year, climate cases in Brazil are still few and far between. It is somewhat unsurprising, therefore, that lawyers and judges alike often frame cases in terms of general environmental law concepts that they are familiar with, and that have been tested by courts time and again, deploying climate arguments tentatively or relegating them to an afterthought.

Despite its transversal nature, meaning that climate policy has effects across policy fields that lie both within and outside of environmental law, ${ }^{62}$ climate law is also very specific in that it is truly global: Environmental matters, even if spanning multiple jurisdictions, are typically more localized in nature. Conversely, the diffuse nature of climate change often renders typical instruments of international environmental law inadequate to deal with its legal ramifications. Climate change is inherently more complex and uncertain than most environmental issues at large. It is, indeed, a super wicked problem, in that it becomes progressively costly and difficult to tackle as time passes; those better positioned to solve the problem are those who caused it and have little incentive to do so; and there is no global government that could address the problem institutionally. ${ }^{63}$

It is very much needed, therefore, that the relevant actors develop and apply legal instruments that are apt to address climate matters' specificities. ${ }^{64}$ Lawyers are especially well-positioned to contribute to the continued development of climate law through litigation, academia, and policy advocacy.

\footnotetext{
${ }^{60}$ See generally Michael B. Gerrard, The Role of Lawyers in Decarbonizing Society, 72 STAN. L. REV. 112 (2020).

${ }^{61}$ Yearly Statistics, NATIONAL COUNCIL OF JUSTICE (CNJ), https://paineis.cnj.jus.br/QvAJAXZfc/opendoc.htm?document= qvw_1\%2FPainelCNJ.qvw\&host=QVS\%40neodimio03\&anonymous=true\&sheet=shResumoDespFT.

${ }^{62}$ See Chris Hilson, It's All About Climate Change, Stupid! Exploring the Relationship Between Environmental Law and Climate Law, 25 J. ENV'T L. 359-70 (2013).

${ }^{63}$ See Richard Lazarus, Super Wicked Problems and Climate Change: Restraining the Present to Liberate the Future, 94 CoRnell L. REV. 1153 (2009).

${ }^{64}$ See Cinnamon Carlarne, Delinking International Environmental Law \& Climate Change, 4 MICH. J. ENV‘T \& ADMIN. L. 1 (2014).
} 
At the current stage of climate litigation, in Brazil and globally, it is fundamental that case strategy is thoroughly thought out, as a case may have repercussions extending well beyond the matter at hand: Differences in legal systems aside, the circulation of tested climate litigation arguments is a powerful tool to consolidate the domain of climate law. The process of affirmation of a new legal domain is a lengthy one, however, and the climate emergency requires urgent measures. It is of strategic importance for climate litigation, therefore, to frame climate concepts, both legal and scientific, in terms of legal concepts that are particular to each jurisdiction, thus providing a working legal framework for courts to work with.

A prominent example in Brazilian law is the general environmental law concept of a causal nexus, ${ }^{65}$ the linkage between a conduct and an outcome that is indispensable for configuration of environmental damages. To date, to the exception of a case filed by the Public Prosecution Service seeking climate damages tied to deforestation in the Amazon, ${ }^{66}$ climate cases have stopped short of claiming redress of climate harms, presumably because of the high bar set by the causal nexus test. If we want to move forward, we must consider the possibility that Brazilian courts will treat climate harms as a subset of environmental harms and prepare accordingly, for instance by translating climate attribution science ${ }^{67}$ in measurable and verifiable terms. Going against the grain is important to push the boundaries of the climate debate, but, strategically, so is framing arguments in terms of well-known and tested general legal concepts.

The second gap concerns the need to enhance dialogue between experts and courts. The role of interpreting and decoding climate science in legal terms, in order to bridge this gap, is also one that can and should be prominently played by lawyers. To do so effectively, a couple of initiatives are in order. First, it is necessary to differentiate climate science from environmental science at large. Specialized environmental courts in Brazil can be well-versed in environmental science, but it is important that lawyers lay out the specifics of climate science as clearly as possible, with the indispensable support of quantitative and qualitative data. Second, it is important to tailor scientific findings by jurisdiction, in order to account for different greenhouse gas emissions profiles. Brazil, for instance, is highly biodiverse, and home to the largest extension of Amazon rainforest. The country's emissions are largely driven by land use and deforestation, as opposed to those countries in the Global North that mainly derive from energy or industrial emissions. Third, it is important to bring climate economists into the fold in order to quantify the adverse economic impacts of climate inaction.

Encouraging examples of courts showing deference to climate science include the Dutch court's adoption of Intergovernmental Panel on Climate Change (IPCC) scenarios as a judicial standard in Urgenda ${ }^{68}$ and Brazil's Climate Fund Case, in which a public hearing was ordered ex officio by the court, ${ }^{69}$ in recognition that the subject requires interdisciplinary knowledge regarding legal, scientific, socio-environmental, and economic aspects.

The third gap concerns the mismatch between international and domestic climate commitments. Brazil has had a National Policy on Climate Change (PNMC) in force since 2009, and, in December 2020, presented its second-or, in official terms, its first revised-Nationally Determined Contribution (NDC) to the Paris Agreement. The alignment between the two documents-which represent, respectively, the country's climate commitments in the national and international levels - is fragile at best. Indeed, the Brazilian NDC is at odds with the commitments

\footnotetext{
${ }^{65}$ See Paulo Affonso Leme Machado, STJ and Causal Nexus in Environmental Civil Liability, 14 VEREDAS DO DIREITO. Direito Ambiental e Desenvolvimento Sustentável 30, (2019).

${ }^{66}$ See Public Civil Action No. 1005885-78.2021.4.01.3200/AM (Braz.).

${ }^{67}$ See generally Richard Heede, Tracing Anthropogenic CO2 and Methane Emissions to Fossil Fuel and Cement Producers, 1854-2010, 122 Climatic Change 229-41 (2014).

${ }^{68}$ Hof s-Gravenhage 9 oktober 2018, AB 2018, 417 m.nt. GA van der Veen, Ch.W. Backes (Staat der Nederlanden/Stichting Urgenda) (Neth.), http://blogs2.law.columbia.edu/climate-change-litigation/wp-content/uploads/sites/16/non-us-casedocuments/2020/20200113_2015-HAZA-C0900456689_judgment.pdf.

${ }^{69}$ See Action for Non-Compliance with a Fundamental Precept (ADPF) 708 (Braz.).
} 
set forth in the PNMC, and, even more significantly, both lack the subsequent policies that are urgently needed to translate the commitments into effective implementation, particularly with regard to verifiable interim targets and regular progress assessments. A "race to the top" of long-term climate ambition is welcome, but it will only mean something if translated into immediate and concrete action.

Furthermore, the government's defense in a climate claim brought by a group of youth, ${ }^{70}$ aiming at challenging the insufficient level of ambition of the new NDC, was precisely that of lack of standing to discuss, before a domestic court, what the government deems as a commitment that could only be challenged, if at all, at the international level.

There is also a disconnect between Brazil's climate commitments and those of the private sector: Private companies have been adhering to international climate frameworks that, although welcome initiatives, are in dire lack of harmonization and comparability. While it is true that, in Brazil, private entities still do not have mandatory emission reduction goals, Brazil's climate commitments can only be accomplished if duly translated internally, including, and especially, for the private sector.

Again, respite can be found in the form of climate litigation. ${ }^{71}$ In Milieudefensie $v$. Shell, ${ }^{72}$ a District Court of The Hague, Netherlands, ordered Shell to reduce its CO2 emissions by fortyfive percent by 2030, compared to 2019 levels, covering the entire economic group, and Scope $3^{73}$ emissions, which include suppliers and consumers. For the first time, the climate obligations recognized in court do not belong to the government, but to a private company. The court interpreted the Dutch Civil Code in light of the Paris Agreement, United Nations Guiding Principles on Business and Human Rights (UNGP principles) and OECD rules, concluding that Shell has an obligation to align itself with the Paris targets.

The decision is a milestone in climate litigation and has important practical implications. The recognition that the Paris Agreement also binds the private sector is unprecedented and should drive new litigation around the world-with the possible inclusion of Brazil, in spite of differences in legal systems - seeking to compel other companies to align with Paris goals.

Neubauer v. Germany ${ }^{74}$ is another landmark case in terms of how to translate Paris commitments into practice. The claim challenged the constitutionality of certain provisions of Germany's Federal Climate Protection Act (Bundes-Klimaschutzgesetz); shortly after the decision, the German government raised the country's climate ambition, raising mitigation targets to net-zero greenhouse gas emissions by 2045 , and adding a target to cut emissions by sixty-five percent by 2030. The case offers a prime example of the relevance of strategic climate litigation as a governance instrument. The main takeaway from Neubauer, however, is not the court mandate to review climate ambition, the following increase of ambition by the German government, nor the deployment of intergenerational equity arguments in the form of a balancing of overspending the climate budget and future restrictions of freedom. These are important features of the case, but its most remarkable lesson lies in the fact that the decision enshrined the realization that tackling the climate emergency requires urgent measures. Beyond long-term goals, the court recognized the need to formulate concrete, transparent intermediate specifications on how to get there, "at the earliest possible stage." ${ }^{\prime 5}$ Indeed, the court ruled that the statutory provisions on adjusting the

\footnotetext{
${ }^{70}$ Popular Action No. 5008035-37.2021.4.03.6100/SP (Braz.).

${ }^{71}$ See Lennart Wegener, Can the Paris Agreement Help Climate Change Litigation and Vice Versa?, 9 TRANSNAT'L ENV'T L. 17-36 (2020).

${ }^{72}$ Rb. den Haag, Case C/09/571932, Milieudefensie v. Shell, ECLI:NL:RBDHA:2021:5337 (May 26, 2021) (Neth.).

${ }^{73}$ Corporate Value Chain (Scope 3) Accounting and Reporting Standard (2011), GreENHOUSE Gas Protocol https:// ghgprotocol.org/sites/default/files/standards/Corporate-Value-Chain-Accounting-Reporing-Standard_041613_2.pdf

${ }^{74} \mathrm{BVerfG}, 1$ BvR 2656/18, Mar. 24, 2021, paras. 1-270, https://www.bundesverfassungsgericht.de/SharedDocs/ Entscheidungen/EN/2021/03/rs20210324_1bvr265618en.html;jsessionid=871C7BA24BF9A1FCC8B80381BAC06F15.2_ cid386.

${ }^{75} \mathrm{Id}$.
} 
reduction pathway for greenhouse gas emissions from 2031 onwards are not sufficient to ensure that the necessary transition to climate neutrality is achieved in time, and that the legislator must enact provisions by December 31, 2022 that specify in greater detail how the reduction targets for greenhouse gas emissions are to be adjusted for periods after $2030 .^{76}$

Climate litigation, therefore, offers rather concrete avenues to bridge the gap between international and domestic climate regimes; again, lawyers are a vital piece of the puzzle.

\section{E. Concluding Remarks}

The current wave of climate litigation in Brazil represents an unprecedented opportunity to substantially advance climate law. Brazil has joined the group of countries whose constitutional courts have spoken, or are in the process of doing so, on climate disputes, and has the opportunity to contribute to strengthening the body of climate decisions that has been widely studied and applied by lawyers and scientists worldwide.

The importance of climate litigation to advance climate law cannot be understated. Climate litigation, therefore, needs to be carefully crafted so that it makes sense not only within the confines of the case or narrative at hand, but also in the larger context of the development of a new area of the law.

This can be done in several ways, and this article aims, based on my experience both in academia and as a litigator, at identifying three avenues that I deem will be crucial for the advance of strategic climate litigation. First, it analyzes how climate claims can be construed with arguments that are impervious to the political question doctrine. Second, it explores possibilities of bringing claims against private entities, challenging more granular obligations arising out of ESG frameworks. Third, it discusses the role of lawyers in bridging conceptual and empirical gaps, namely those between environmental law and climate law, between scientific experts and courts, and between international and domestic climate change regimes.

Attorney Julia Olson's statement at the Juliana case hearing before the U.S. Ninth Circuit Court of Appeals illustrates the growing relevance of climate litigation: "If we look back on the twentieth century, we can see that race and sex discrimination were the constitutional questions of that era. And when our great-grandchildren look back at the twenty-first century, they will see that government-sanctioned climate destruction was the constitutional issue of this century." 77

Climate litigation, therefore, is a relevant means to foster climate action and to contribute to the country's progress in accomplishing its climate commitments. Equally significantly, it also entails the possibility to shift the Overton Window of climate dialogue, promoting the development of climate law and the effectiveness of the constitutional issue of the twenty-first century.

\footnotetext{
${ }^{76}$ BVerfG, Press Release No. 31/2021 of 29 April 2021, https://www.bundesverfassungsgericht.de/SharedDocs/ Pressemitteilungen/EN/2021/bvg21-031.html.

${ }^{77}$ See Carolyn Korman, The Right to a Stable Climate is the Constitutional Question of the Twenty-First Century, NEw YORKER (Jun. 15, 2019).
}

Cite this article: Lehmen A (2021). Advancing Strategic Climate Litigation in Brazil. German Law Journal 22, 1471-1483. https://doi.org/10.1017/glj.2021.82 